\title{
Is the presence of Helicobacter pylori in the dental plaque of patients with chronic periodontitis a risk factor for gastric infection?
}

\author{
Mohammed Al Asqah BDS ${ }^{1}$, Nawaf Al Hamoudi BDS ${ }^{1}$, Sukumaran Anil BDS PhD¹, \\ Abdulrahman Al jebreen MD FRCPC ${ }^{2}$, Waleed Khalid Al-hamoudi MD2
}

\begin{abstract}
M Al Asqah, N Al Hamoudi, S Anil, A Al jebreen, WK Al-hamoudi. Is the presence of Helicobacter pylori in the dental plaque of patients with chronic periodontitis a risk factor for gastric infection? Can J Gastroenterol 2009;23(3):177-179.
\end{abstract}

BACKGROUND: Helicobacter pylori is considered to be a pathogen responsible for gastritis and peptic ulcers, and a risk factor for gastric cancer. A periodontal pocket in the teeth of individuals with chronic periodontitis may function as a reservoir for $\mathrm{H}$ pylori.

OBJECTIVE: The present study was undertaken to evaluate whether the presence of $\mathrm{H}$ pylori in the dental plaque of patients with and without periodontitis correlates with gastric involvement.

METHODS: A total of 101 patients with dyspepsia were included in the present study. Subjects were divided into periodontitis and nonperiodontitis groups. For the detection of $\mathrm{H}$ pylori in dental plaque, samples were collected from two teeth using a periodontal curette. Subgingival plaque was obtained by inserting two sterile paper points into periodontal pockets for $20 \mathrm{~s}$. This was followed by an upper gastrointestinal endoscopy and antral biopsies.

RESULTS: Sixty-five per cent of patients had dental plaque positive for $\mathrm{H}$ pylori and more than $50 \%$ harboured the bacteria in their stomach. Periodontitis patients had a significantly higher percentage of $\mathrm{H}$ pylori in their dental plaque $(79 \%$ versus $43 \% ; \mathrm{P}<0.05)$ and the stomach $(60 \%$ versus $33 \% ; \mathrm{P}<0.05)$ than patients with no periodontitis. Additionally, $78 \%$ of patients from the periodontitis group versus only $30 \%$ from the nonperiodontitis group had a positive test result for the coexistence of $\mathrm{H}$ pylori in both dental plaque and the stomach.

CONCLUSION: Patients with poor oral hygiene have a higher prevalence of $H$ pylori in dental plaque and in the stomach. This finding suggests that the oral cavity may be a reservoir for $\mathrm{H}$ pylori, and potentially a source of transmission or reinfection.

Key Words: Helicobacter pylori; Oral hygiene; Periodontitis

$\mathrm{H}$ elicobacter pylori is a microaerophilic, Gram-negative, spiral and mobile bacterium that is believed to be one of the major factors responsible for gastritis, gastroduodenal ulcers and gastric cancer $(1,2)$. Studies have identified the microorganism in dental plaque and saliva, implicating the oral cavity as a potential reservoir for $\mathrm{H}$ pylori or as a possible route of transmission to other sites. The oral cavity can act as an extragastric reservoir for $\mathrm{H}$ pylori, which may lead to recurrent gastric infection (3).

Avcu et al (4) observed that patients with poor oral hygiene were most likely to have $H$ pylori in the oral cavity. They also suggested that $H$ pylori could recur in the stomach of these patients after triple therapy more frequently than in patients

\section{La présence d'Helicobacter pylori dans la plaque dentaire de patients souffrant de parodontite chronique est-elle un facteur de risque de gastrite?}

HISTORIQUE : Helicobacter pylori est considéré comme l'un des agents pathogènes responsables de la gastrite et de l'ulcère gastroduodénal et comme un facteur de risque à l'égard du cancer de l'estomac. Chez les personnes souffrant de parodontite chronique, les poches parodontales pourraient constituer des réservoirs d'H. pylori.

OBJECTIF : La présente étude a été entreprise afin de vérifier si la présence d'H. pylori dans la plaque dentaire de patients souffrant ou non de parodontite est en corrélation avec une atteinte gastrique.

MÉTHODES : En tout, 101 patients souffrant de dyspepsie ont participé à l'étude. Les sujets ont été répartis en deux groupes selon qu'ils souffraient ou non de parodontite. Pour le dépistage d'H. pylori dans la plaque dentaire, des échantillons ont été prélevés sur deux dents au moyen d'une curette parodontale. Les échantillons de plaque sous-gingivale ont été obtenus par l'insertion de deux coins de papier stérile dans des poches parodontales pendant $20 \mathrm{~s}$. Cette étape a été suivie d'une endoscopie des voies digestives hautes pour prélèvement de biopsies antrales.

RÉSULTATS : Soixante-cinq pour cent des patients présentaient une plaque dentaire $H$. pylori-positive et plus de $50 \%$ hébergeaient la bactérie dans leur estomac. Les patients atteints de parodontite présentaient un pourcentage significativement plus élevé d'H. pylori au niveau de la plaque dentaire ( $79 \%$ vs $43 \%$; $<0,05 \%$ ) et de l'estomac (60\% vs $33 \%$; $\mathrm{P}<0,005)$, comparativement aux patients indemnes de parodontite. De plus, $78 \%$ des patients du groupe souffrant de parodontite, contre $30 \%$ seulement des patients indemnes, avaient un résultat positif pour ce qui est de la coexistence d'H. pylori au niveau de la plaque dentaire et de l'estomac.

CONCLUSION : On note une prévalence plus élevée d'H. pylori dans la plaque dentaire et l'estomac des patients dont l'hygiène dentaire laisse à désirer. Cette observation donne à penser que la cavité buccale pourrait constituer un réservoir d'H. pylori et devenir une source potentielle de transmission ou de réinfection.

with good oral hygiene. The findings of Andersen et al (5) justify the suggestion that dental plaque serves as a reservoir for this pathogen. They demonstrated the ability of $\mathrm{H}$ pylori to coaggregate with Fusobacterium nucleatum and Fusobacterium periodonticum, which are early and late colonizers, repectively, of the mouth.

Dye et al (6) found a positive association between $H$ pylori seropositivity and periodontitis in an epidemiological study. They suggested that periodontitis can be a risk factor for $\mathrm{H}$ pylori infection. Umeda et al (7) compared the prevalence of $H$ pylori in patients with and without periodontal pockets and showed a higher prevalence of the bacteria in patients with deep periodontal pockets. In contrast, other studies $(8-10)$ failed

${ }^{1}$ College of Dentistry; ${ }^{2}$ Department of Gastroenterology, College of Medicine, King Saud University, Riyadh, Saudi Arabia

Correspondence: Dr Waleed Khalid Al-hamoudi, College of Medicine, King Saud University, University Road, Riyadh, Central province 10774,

Saudi Arabia. Telephone 966-505-240588, fax 966-146-71217, e-mail walhamoudi@gmail.com

Received for publication September 4, 2008. Accepted October 30, 2008 
TABLE 1

Prevalence of periodontitis by sex

\begin{tabular}{lccc}
\hline & Men & Women & Total \\
\hline Periodontitis group & $35(56)$ & $27(44)$ & $62(61)$ \\
Nonperiodontitis group & $21(54)$ & $18(46)$ & $39(39)$ \\
Total & $56(55)$ & $45(45)$ & $101(100)$ \\
\hline
\end{tabular}

Data presented as $n$ (\%)

TABLE 2

Prevalence of Helicobater pylori in the dental plaque of patients with and without periodontitis

\begin{tabular}{llcc}
\hline & \multicolumn{2}{c}{$\boldsymbol{H}$ pylori in dental plaque } & \\
\cline { 2 - 3 } & Present & Absent & Total \\
\hline Periodontitis group & $49 *(79)$ & $13(21)$ & $62(61)$ \\
Nonperiodontitis group & $17(43)$ & $22(57)$ & $39(39)$ \\
Total & $66(65)$ & $35(35)$ & $101(100)$ \\
\hline
\end{tabular}

Data presented as $n(\%) .{ }^{*} P<0.05$

to detect $H$ pylori in the subgingival plaque of patients with a gastric infection.

Studies regarding the prevalence of $\mathrm{H}$ pylori in dental plaque, and its correlation with systemic conditions are inconclusive. The present study is one of the very few conducted to evaluate the prevalence of $H$ pylori in both dental plaque and the gastric mucosa of symptomatic patients admitted to a gastroenterology department.

\section{METHODS}

One hundred one patients attending the gastroenterology unit of the King Saud University Hospital, Riyadh, Saudi Arabia, were asked to participate in the study. The purpose of the study was explained to the patients and consents were obtained. The study was approved by the hospital's ethics committee. All patients had a complaint of dyspepsia and underwent gastroscopy and antral biopsies. Biopsy samples were analyzed immediately using a rapid urease test kit.

All selected patients were nonsmokers, and the following exclusion criteria were used to achieve a more homogenous study population: diabetes, pregnancy, HIV-positive, previous treatment of a peptic ulcer, cancer, antibiotic therapy during the previous two months, periodontal therapy within the past year, signs of severe periodontal infection, severe dental caries and the recent use of nonsteroidal anti-inflammatory drugs.

Based on periodontal status, subjects were divided into two groups (with and without chronic periodontitis). Only patients exhibiting bleeding on probing and at least four teeth with a probing depth of $3 \mathrm{~mm}$ or more were assigned to the chronic periodontitis group $(n=62)$. The remainder of the individuals were considered healthy oral cavity subjects $(n=39)$. The probing depth, plaque index, bleeding on probing and clinical attachment level were recorded by the same investigator.

For the detection of $\mathrm{H}$ pylori in dental plaque, samples were collected from the oral cavity after the clinical periodontal examination. A sterile universal curette was used to collect plaque samples from two teeth with deep periodontal pockets.

\section{The rapid urease test}

$\mathrm{H}$ pylori was detected by a commercially available rapid gastric urease test kit (Lencomm Trade International, Poland). The samples were immediately inoculated into the rapid urease
TABLE 3

Prevalence of Helicobacter pylori in the stomach of patients with and without periodontitis

\begin{tabular}{lccc}
\hline & \multicolumn{2}{c}{$\boldsymbol{H}$ pylori in stomach } & \\
\cline { 2 - 3 } & Present & Absent & Total \\
\hline Periodontitis group & $37^{*}(60)$ & $25(40)$ & $62(61)$ \\
Nonperiodontitis group & $13(33)$ & $26(67)$ & $39(39)$ \\
Total & $50(50)$ & $51(50)$ & $101(100)$ \\
\hline
\end{tabular}

Data presented as $n$ (\%). ${ }^{*} P<0.05$

test gel. If the test gel colour changed from yellow to red within $20 \mathrm{~min}$, up to a maximum of $60 \mathrm{~min}$ (as recommended by the manufacturer), the sample was considered positive for $\mathrm{H}$ pylori.

\section{Statistical analysis}

Statistical analysis of data was performed with GraphPad software (InStat, USA). The $\chi^{2}$ test was used to analyze the association between the detection frequencies of $H$ pylori in the dental plaque of patients with and without periodontitis, and the presence or absence of $H$ pylori in the stomach. $\mathrm{P}<0.05$ was considered statistically significant.

\section{RESULTS}

A total of 101 subjects with a mean $( \pm$ SD) age of $40.77 \pm 14.15$ years consented and were selected for the study. Of these patients, 56 were men and 45 were women. All patients were subjected to periodontal examination. Sixtytwo participants $(61 \%)$ were diagnosed with periodontitis and 39 (39\%) had healthy oral cavities (Table 1).

The prevalence of $H$ pylori in the dental plaque of the study cohort was $65 \%$ (Table 2). Patients with periodontitis had a significantly higher rate of $H$ pylori-positive test results (79\%), compared with only $43 \%$ of patients without periodontitis $(\mathrm{P}<0.05)$.

Among all study participants, 50 (50\%) harboured $\mathrm{H}$ pylori in the stomach (Table 3). The periodontitis subjects had a statistically higher prevalence $(60 \%)$ of $\mathrm{H}$ pylori in the stomach than the nonperiodontitis group (33\%). Table 4 shows the prevalence of $H$ pylori in the dental plaque of patients with and without periodontitis who harboured $\mathrm{H}$ pylori in the stomach. Twenty-nine (78\%) of 37 patients with periodontitis harboured $\mathrm{H}$ pylori in their plaque samples. However, only four (30\%) of 13 subjects without periodontitis harboured $H$ pylori in their dental plaque, a difference that was statistically significant $(\mathrm{P}<0.05)$.

\section{DISCUSSION}

The oral cavity provides a gateway between the external environment and the gastrointestinal tract, and it facilitates both food ingestion and digestion. Poor oral hygiene and tooth loss can potentially affect gastrointestinal flora and nutritional status, and consequently be implicated in the development of chronic gastrointestinal diseases (11). Poor dental health, tooth loss or both, have been associated with an increased risk for gastrointestinal malignancies including oral, esophageal and gastric cancers (12-16). Several studies (4,17-19) have suggested that dental plaque is a reservoir for $\mathrm{H}$ pylori. The presence of $H$ pylori has been universally associated with chronic gastritis and strongly associated with duodenal ulcers. Studies have also identified the microorganism in dental plaque and saliva, implicating the oral cavity as a potential reservoir for $\mathrm{H}$ pylori, or as a possible route of transmission to other sites. 
Riggio and Lennon (20) studied the presence of $H$ pylori in the subgingival plaque of adult periodontitis patients. They found that $38 \%$ of the subjects with deep periodontal pockets were positive for $H$ pylori. In a national survey of 4504 subjects, Dye et al (6) observed that nearly $41 \%$ of individuals with periodontitis were $H$ pylori seropositive. Moreover, $\mathrm{H}$ pylori was detected in more than $50 \%$ of patients with periodontitis who harboured $H$ pylori in their stomach (7). The results of the present study are in agreement with previous studies. Fifty per cent of the study subjects with periodontitis were positive for $\mathrm{H}$ pylori in dental plaque. Also, among the subjects who were positive for $\mathrm{H}$ pylori in the stomach, $74 \%$ had chronic periodontitis.

Conflicting reports exist in the literature regarding the presence of $\mathrm{H}$ pylori in the oral cavity and its relation to its presence in the stomach $(6,8,9)$. Asikainen et al $(8)$ were not able to detect $H$ pylori in the subgingival plaque of 336 patients with periodontitis, although no analysis for the presence of this bacteria in the stomach of those patients was performed. In another study, Oshowo et al (9) failed to demonstrate any correlation between the presence of $\mathrm{H}$ pylori in the stomach and dental plaque, and suggested that the oral cavity may not be a reservoir for reinfection. These conflicting observations could be attributed to the diversity of the populations studied, sample collection methods or the specificity of the methods used for the detection of $\mathrm{H}$ pylori.

Although several studies investigated the prevalence of $\mathrm{H}$ pylori in the dental plaque of patients with and without

\section{REFERENCES}

1. Dunn BE, Cohen H, Blaser MJ. Helicobacter pylori. Clin Microbiol Rev 1997;10:720-41.

2. Taylor DN, Blaser MJ. The epidemiology of Helicobacter pylori infection. Epidemiol Rev 1991;13:42-59.

3. Miyabayashi H, Furihata K, Shimizu T, Ueno I, Akamatsu T. Influence of oral Helicobacter pylori on the success of eradication therapy against gastric Helicobacter pylori. Helicobacter 2000;5:30-7.

4. Avcu N, Avcu F, Beyan C, et al. The relationship between gastricoral Helicobacter pylori and oral hygiene in patients with vitamin B12-deficiency anemia. Oral Surg Oral Med Oral Pathol Oral Radiol Endod 2001:92:166-9.

5. Andersen RN, Ganeshkumar N, Kolenbrander PE. Helicobacter pylori adheres selectively to Fusobacterium spp. Oral Microbiol Immunol 1998;13:51-4.

6. Dye BA, Kruszon-Moran D, McQuillan G. The relationship between periodontal disease attributes and Helicobacter pylori infection among adults in the United States. Am J Public Health 2002;92:1809-15.

7. Umeda M, Kobayashi H, Takeuchi Y, et al. High prevalence of Helicobacter pylori detected by PCR in the oral cavities of periodontitis patients. J Periodontol 2003;74:129-34.

8. Asikainen S, Chen C, Slots J. Absence of Helicobacter pylori in subgingival samples determined by polymerase chain reaction. Oral Microbiol Immunol 1994:9:318-20.

9. Oshowo A, Tunio M, Gillam D, et al. Oral colonization is unlikely to play an important role in Helicobacter pylori infection. Br J Surg 1998;85:850-2.

10. Chitsazi MT, Fattahi E, Farahani RM, Fattahi S. Helicobacter pylori in the dental plaque: Is it of diagnostic value for gastric infection? Med Oral Patol Oral Cir Bucal 2006;11:E325-8.
TABLE 4

Prevalence of Helicobacter pylori in the dental plaque of patients who harboured $H$ pylori in the stomach

\begin{tabular}{lccc}
\hline & \multicolumn{2}{c}{$\boldsymbol{H}$ pylori in dental plaque } & \\
\cline { 2 - 3 } & Present & Absent & Total \\
\hline Periodontitis group & $29 *(78)$ & $8(22)$ & $37(74)$ \\
Nonperiodontitis group & $4(30)$ & $9(70)$ & $13(26)$ \\
Total & $33(66)$ & $17(34)$ & $50(100)$ \\
\hline
\end{tabular}

Data presented as $n$ (\%). ${ }^{*} P<0.05$

periodontitis, most did not investigate the simultaneous existence of the bacterium in the stomach (6). In the present study, the presence of $\mathrm{H}$ pylori was examined in both dental plaque and the gastric mucosa of symptomatic patients presenting to a gastroenterology clinic. A higher number of subjects with periodontitis had a coexistent presence of the bacterium in the stomach and in dental plaque compared with nonperiodontitis patients. The significantly higher prevalence of $H$ pylori in the periodontitis group may be related to poor oral hygiene and the presence of periodontal pockets. Miyabayashi et al (3) suggested that $H$ pylori in dental plaque may be a risk factor for recurrent gastric infection. The results of the current study support this suggestion and highlight the importance of the oral cavity and dental plaque as reservoirs for $\mathrm{H}$ pylori as a potential source for reinfection after eradication treatment. A combination of professional medical and dental treatment modalities may be required for individuals with $H$ pylori infection.

11. Dowsett SA, Kowolik MJ. Oral Helicobacter pylori: Can we stomach it? Crit Rev Oral Biol Med 2003;14:226-33.

12. Marshall JR, Graham S, Haughey BP, et al. Smoking, alcohol, dentition and diet in the epidemiology of oral cancer. Eur J Cancer B Oral Oncol 1992;28B:9-15.

13. Zheng TZ, Boyle P, Hu HF, et al. Dentition, oral hygiene and risk of oral cancer: A case-control study in Beijing, People's Republic of China. Cancer Causes Control 1990;1:235-41.

14. Balaram P, Sridhar H, Rajkumar T, et al. Oral cancer in southern India: The influence of smoking, drinking, paan-chewing and oral hygiene. Int J Cancer 2002;98:440-5.

15. Velly AM, Franco EL, Schlecht N, et al. Relationship between dental factors and risk of upper aerodigestive tract cancer. Oral Oncol 1998;34:284-91.

16. Watabe K, Nishi M, Miyake H, Hirata K. Lifestyle and gastric cancer: A case-control study. Oncol Rep 1998;5:1191-4.

17. Peach HG, Pearce DC, Farish SJ. Helicobacter pylori infection in an Australian regional city: Prevalence and risk factors. Med J Aust 1997;167:310-3.

18. Ozdemir A, Mas MR, Sahin S, Saglamkaya U, Ateskan U. Detection of Helicobacter pylori colonization in dental plaques and tongue scrapings of patients with chronic gastritis. Quintessence Int 2001;32:131-4.

19. Kim N, Lim SH, Lee KH, et al. Helicobacter pylori in dental plaque and saliva. Korean J Intern Med 2000;15:187-94.

20. Riggio MP, Lennon A. Identification by PCR of Helicobacter pylori in subgingival plaque of adult periodontitis patients. J Med Microbiol 1999;48:317-22. 


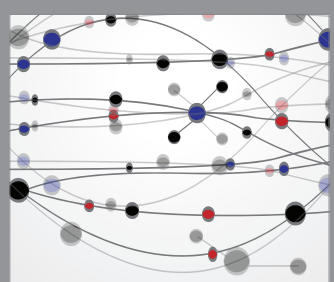

The Scientific World Journal
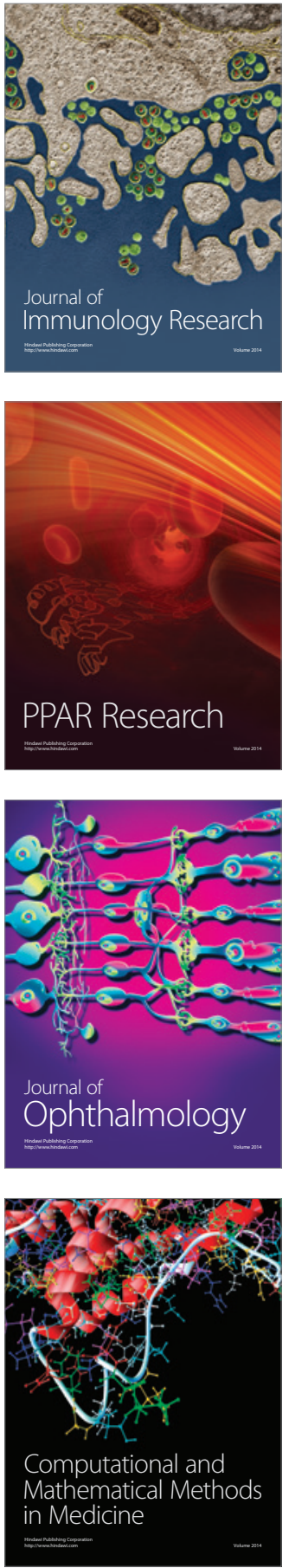

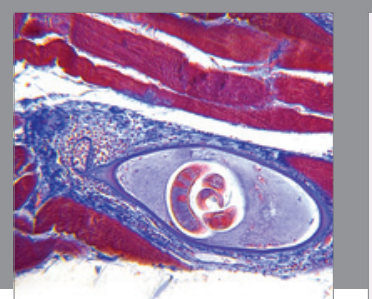

Gastroenterology Research and Practice

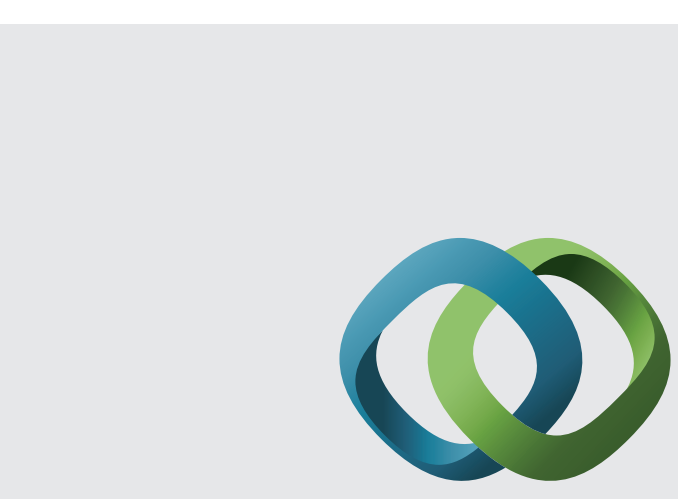

\section{Hindawi}

Submit your manuscripts at

http://www.hindawi.com
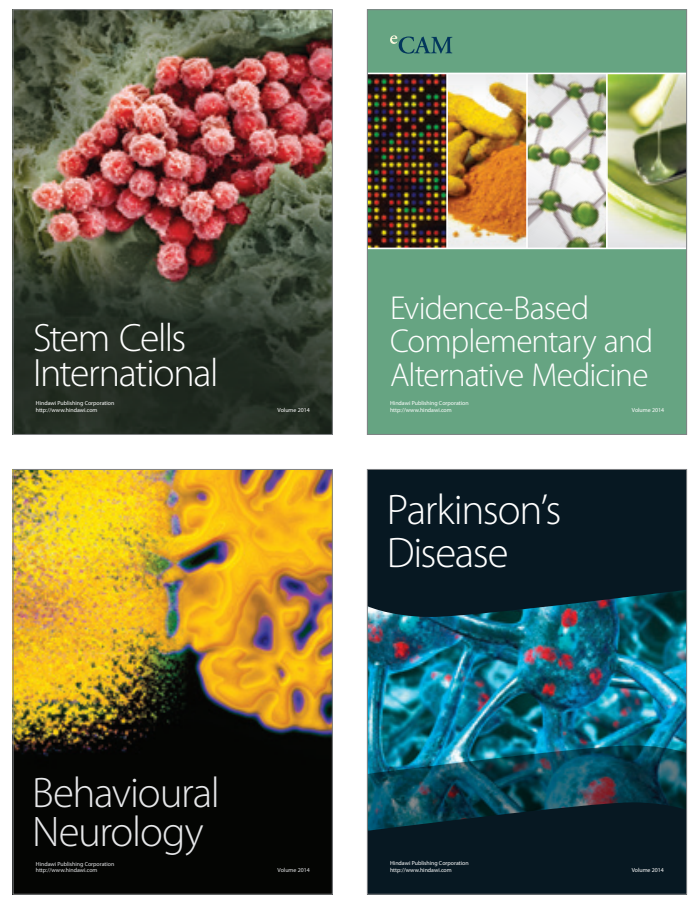
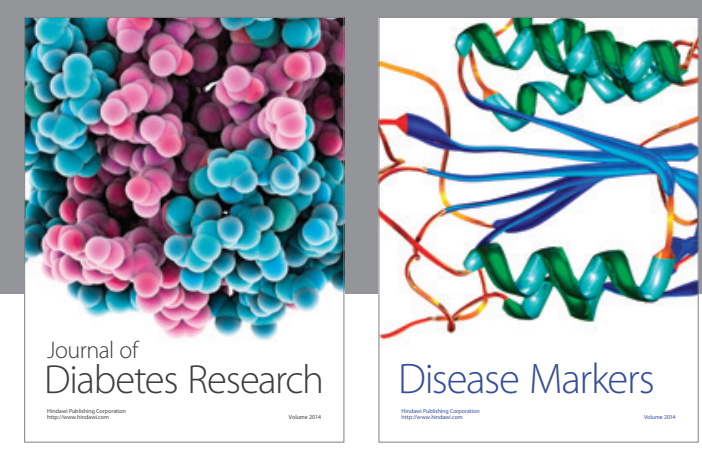

Disease Markers
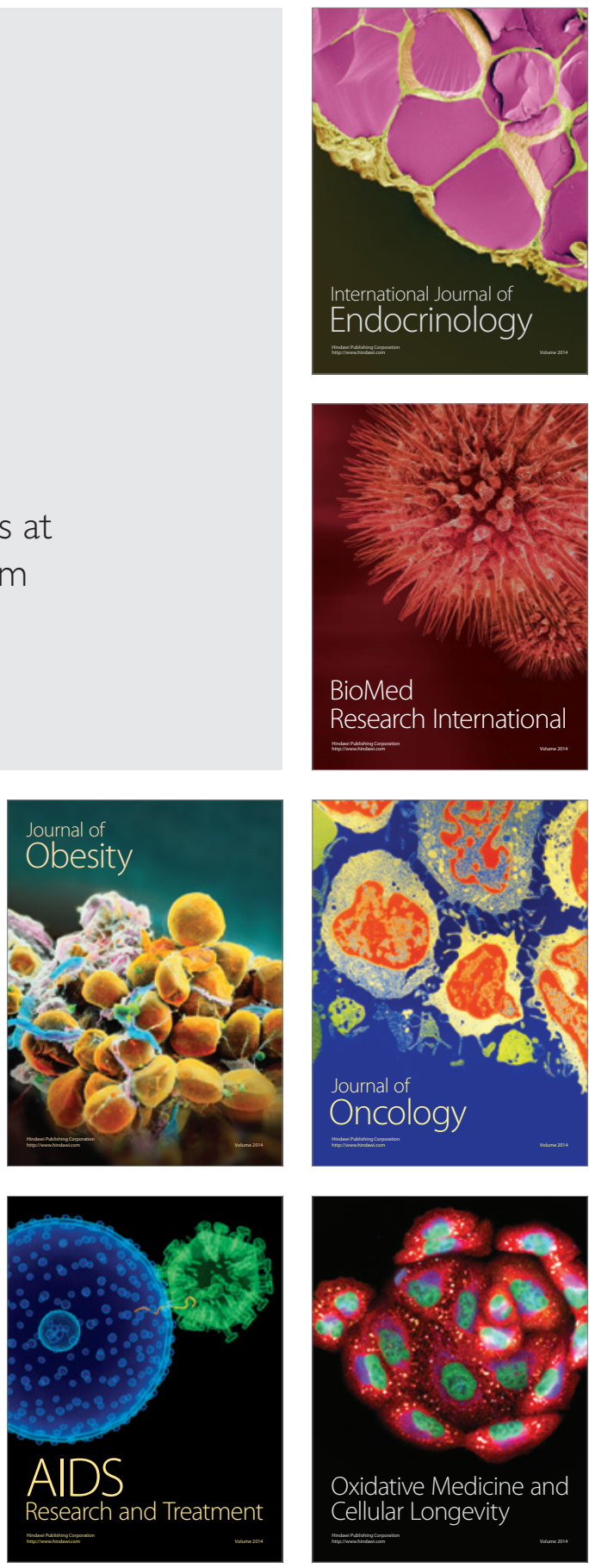